\title{
INFLUENCIA DEL CONTENIDO SALINO DEL AGUA DE BEBIDA ANIMAL SOBRE LOS COMPONENTES PRINCIPALES DE LA FASE SOLUBLE EN LECHE DE VACAS INDIVIDUALES
}

\author{
Sbodio, O. A. "; ReVelli, G. R. 2; Tercero, E. J. ${ }^{1}$; \\ Gallardo, M. R. ${ }^{3}$ \& VAltorta, S. E. ${ }^{3,4}$
}

\begin{abstract}
RESUMEN
Se estudió el efecto del contenido salino del agua de bebida animal sobre la concentración de los componentes principales de la fase soluble de la leche: lactosa, sodio, potasio y cloruros. El ensayo se llevó a cabo en un establecimiento lechero comercial perteneciente a la Cooperativa Tambera Nueva Alpina Ltda., ubicada en el departamento Rivadavia, provincia de Santiago del Estero, Argentina, durante los meses de Abril a Noviembre de 2003. Participaron en la experiencia 60 vacas Holando Argentino multíparas (dos, tres y cuatro lactancias), con 40 días posparto, separadas en dos lotes de 30 animales cada uno. Uno de los grupos (T1) bebió agua con niveles promedio de 9.819 $\pm 1.849,80 \mathrm{mg} / \mathrm{L}$ de Sólidos Disueltos Totales (SDT), y el restante (T2) solamente $1.222 \pm 677,19$ $\mathrm{mg} / \mathrm{L}$. No se observaron diferencias significativas entre los componentes analizados considerando ambos tratamientos. Se infiere que el contenido salino del agua de bebida animal no influye sobre la concentración de lactosa, sodio, potasio y cloruros de la leche.
\end{abstract}

Palabras clave: vacas lecheras, agua de bebida, salinidad, fase soluble de la leche.

\section{SUMMARY}

\section{Influence of salt content in drinking water on the components of the soluble phase of milk in individual cows}

We studied the effect of salt content in drinking water on the components of the soluble phase of milk such as lactose, sodium, potassium and chlorides. The study was carried out at a commercial establishment belonging to Cooperativa Tambera Nueva Alpina Ltda., located in Rivadavia department, Santiago del Estero province, Argentina, from April to November of 2003. It included 60 multiparous Holstein cows (two, three and four lactations), with 40 postpartum days, separated into two groups of 30 cows each. We provided one group with a drinking water of Total Dissolved Solids (TDS) content of $9,819 \pm 1,849.80 \mathrm{mg} / \mathrm{L}$ (T1), while the other group (T2) received water with 1,222

\footnotetext{
1.- Instituto de Tecnología de Alimentos (I.T.A.), Facultad de Ingeniería Química, Universidad Nacional del Litoral, C. C. 266, Santa Fe, Argentina. e-mail: sbodio@fiq.unl.edu.ar

2.- Laboratorio Integral de Servicios Analíticos (L.I.S.A.), Cooperativa Tambera Nueva Alpina Ltda., S2340ALB Ceres, Santa Fe, Argentina.

3.- Estación Experimental Agropecuaria Rafaela, INTA, C. C. 22, Rafaela, Santa Fe, Argentina.

4.- Consejo Nacional de Investigaciones Científicas y Técnicas (CONICET), Argentina

Manuscrito recibido el 17 de abril de 2007 y aceptado para su publicación el 12 de noviembre de 2007.
} 
$\pm 677.19 \mathrm{mg} / \mathrm{L}$. Overall, the results showed no significant differences between the two treatments. Therefore, we can conclude that the salt content in water does not influence the concentration of lactose, sodium, potassium and chlorides in milk.

Key words: dairy cows, drinking water, salinity, soluble phase of milk. 